\title{
Giant left anterior descending artery aneurysm in a patient with active systemic lupus erythematosus: a case report
}

\author{
Zipeng Yao ${ }^{1}$, Yanhong Long ${ }^{1}$, Zheng Zong ${ }^{2}$ and Lin Wang ${ }^{3 *}$
}

\begin{abstract}
Background: Although not common, coronary artery aneurysms (CAAs) can develop to over $8 \mathrm{~mm}$ in diameter to become giant CAAs. In the context of systemic lupus erythematosus (SLE), autoantibody- and immune complexmediated atherosclerosis is believed to be the most prevalent cause of aneurysm.

Case presentation: We report the case of a 53-year-old female SLE patient who presented to our hospital with radiating chest pain. Coronary angiography revealed a giant aneurysm in the middle segment of the left anterior descending artery (LAD) and distal subtotal occlusion in the left circumflex artery (LCX). Laboratory testing also identified risk factors such as an abnormal pulmonary enzyme profile, dyslipidemia, and nephritis parameters.To prevent thromboembolism, anticoagulation and antiplatelet therapy were administered. In addition, one stent was implanted at the distal end of the LCX and repeated coronary angiography verified restoration of TIMI grade III flow. The patient was discharged with resolved chest pain. During 6 months of follow-up, the patient is in good health.
\end{abstract}

Conclusions: Our case study, together with 16 recent comparable reports, emphasizes the need for coronary aneurysm screening in SLE patients. It is necessary that thromboembolism, anticoagulation and antiplatelet therapy were administered for CAA.

Keywords: Systemic lupus erythematosus, Coronary artery aneurysm, Coronary angiography

\section{Introduction}

While atherosclerosis is the most prevalent cause of coronary artery aneurysm (CAA) and atherosclerosis is a complication of systemic lupus erythematosus (SLE), CAA formation in SLE patients is rare [1,2]. The prognosis and treatment of CAA are significantly impacted by complications such as thrombosis, distal occlusion, and aneurysm rupture [1]. Currently, however, there is no formal guide for the optimal treatment of CAAs in patients with SLE, and thus, validated clinical studies are urgently

*Correspondence: yaozpg@foxmail.com

${ }^{3}$ Department of Cardiovascular Center, The First Hospital of Jilin University, No.71 Xinmin Street, Changchun 130021, China

Full list of author information is available at the end of the article needed. Here, we present the a case study of a patient with active SLE who presented with a giant CAA.

\section{Case description}

A 53-year-old female patient was admitted to our hospital due to chest pain radiating to the throat. This symptom had developed 1 month previously, and episodes lasted approximately $30 \mathrm{~min}$ before temporarily relief was achieved by oral nitroglycerin administration. The patient had been diagnosed with SLE at the age of 33 years and treated with oral corticosteroids $(12.5 \mathrm{mg} /$ day prednisone), leflunomide, and hydroxychloroquine thereafter. However, no records of periodic interviews or comprehensive documents were available. She denied a history of smoking or drinking Thirteen years after the diagnosis of SLE, she was diagnosed with hypertension with a blood original author(s) and the source, provide a link to the Creative Commons licence, and indicate if changes were made. The images or other third party material in this article are included in the article's Creative Commons licence, unless indicated otherwise in a credit line to the material. If material is not included in the article's Creative Commons licence and your intended use is not permitted by statutory regulation or exceeds the permitted use, you will need to obtain permission directly from the copyright holder. To view a copy of this licence, visit http://creativecommons.org/licenses/by/4.0/. The Creative Commons Public Domain Dedication waiver (http://creativecommons.org/publicdomain/zero/1.0/) applies to the data made available in this article, unless otherwise stated in a credit line to the data. 
pressure of 180/90 $\mathrm{mmHg}$ and began treatment with oral nitrendipine at a dose of $10 \mathrm{mg} /$ day. Physical examination on the current admission revealed a heart rate of 88 beats per minute, a respiration rate of 18 breaths per minute, and a blood pressure of $118 / 62 \mathrm{mmHg}$ with regular heart rhythm and no positive signs, suggesting the hypertension was well controlled by the medication. An electrocardiogram showed normal sinus rhythm, right axis deviation, and no ST-T abnormality, but did reveal fractional shortening by $29 \%$, an ejection fraction of $56 \%$, a small amount of pericardial effusion, and a decreased amplitude of the ventricular septum and left ventricular inferior wall, indicating heart dysfunction. Coronary angiography then revealed a giant aneurysm in the middle segment of the left anterior descending artery (LAD; Fig. 1a and b). In the left circumflex artery (LCX), proximal cystic-like dilatation and distal subtotal occlusion with TIMI grade I flow were observed (Fig. 1b). In addition, varying degrees of dilatation were detected in the middle segment of the right coronary artery (RCA; Fig. 1c).

Laboratory examination results for creatine kinasemuscle/brain $(2.00 \mathrm{ng} / \mathrm{ml}$, normal range $0-4.3 \mathrm{ng} / \mathrm{ml})$ showed that oral nitroglycerin was effective in the early stage. However, elevated serum levels of myoglobin $(155.00 \mathrm{ng} / \mathrm{ml}$, normal range $0-107 \mathrm{ng} / \mathrm{ml})$, cardiac troponin I $(0.62 \mathrm{ng} / \mathrm{ml}$, normal range $0-0.05 \mathrm{ng} / \mathrm{ml})$, and aspartate aminotransferase $(75.4 \mathrm{U} / \mathrm{L}$, normal range 13-35 U/L) indicated irreversible myocardial infraction. In the meantime, the presence of active SLE was verified by the autoimmune profile results, including normal complement C3 (0.82 g/L, normal range 0.7-1.4 g/L) and complement C4 $(0.27 \mathrm{~g} / \mathrm{L}$, normal range $0.1-0.4 \mathrm{~g} / \mathrm{L})$ levels as well as positive detection of anti-dsDNA (IIF) at $1: 10$, homozygous antinuclear antibodies (ANA) at 1:100, and nuclear membrane type ANA at 1:320 along with a high C-reactive protein concentration $(16.20 \mathrm{mg} / \mathrm{L}$, normal range $0-3.5 \mathrm{mg} / \mathrm{L}$ ) and high erythrocyte sedimentation rate $(44 \mathrm{~mm} / 1 \mathrm{~h}$, normal range $0-20 \mathrm{~mm} / 1 \mathrm{~h}$ ). Two risk factors for both SLE and cardiovascular disease also were identified in this case. First, renal parameters were abnormal with a $1+$ positive urine protein, positive urinary nitrite, and elevated levels of urea nitrogen (20.59 $\mathrm{mmol} / \mathrm{L}$, normal range $2.6-7.5 \mathrm{mmol} / \mathrm{L}$ ) and creatinine $(167.8 \mu \mathrm{mol} / \mathrm{L}$, normal range $41-73 \mu \mathrm{mol} / \mathrm{L})$. Additionally, elevated lipid levels including a cholesterol level of $7.17 \mathrm{mmol} / \mathrm{L}$ (normal range $2.6-6.0 \mathrm{mmol} / \mathrm{L}$ ) and triglyceride level of $2.86 \mathrm{mmol} / \mathrm{L}$ (normal range 0.28 $1.8 \mathrm{mmol} / \mathrm{L}$ ) implied dyslipidemia. Finally, The patient had been diagnosed with SLE, CAA,hypertension and acute coronary syndrome.

\section{Therapeutic intervention}

Surgical treatment of giant aneurysms is considered to be a major trauma, so patients choose interventional therapy.At the same time, surgical treatment is our second option. To prevent thromboembolic complications and further myocardial infarction, anticoagulation (lowmolecular-weight calcium heparins, 5,000 U subcutaneously every $12 \mathrm{~h}$ ) and antiplatelet therapy (oral aspirin $100 \mathrm{mg} /$ day and oral clopidogrel hydrogen sulfate $75 \mathrm{mg} /$ day) were administered. At the same time, one stent was implanted at the distal end of the LCX to effectively limit further expansion of the affected coronary segments (Fig. 2a). Repeated coronary angiography revealed that the occlusion was recanalized and TIMI grade III flow

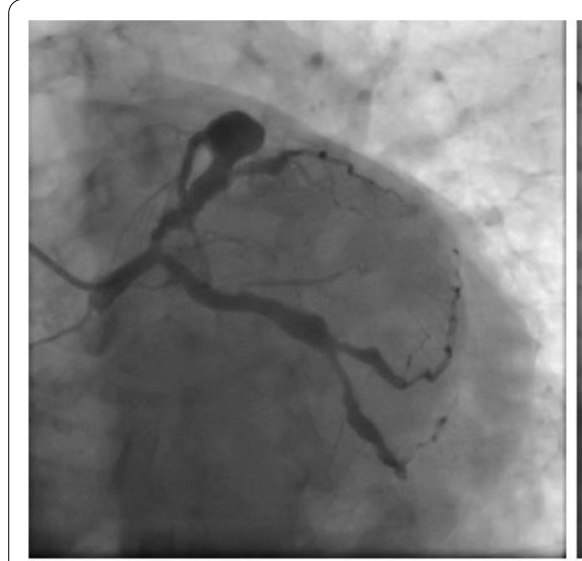

A

Fig. 1 Coronary angiography: A giant aneurysm was observed in the middle of the left anterior descending artery (LAD) (a). In the left circumflex artery (LCX), a proximal cystic-like dilatation and distal subtotal occlusion with TIMI grade I flow were observed (b). Different degrees of dilatation were detected in the middle of the right coronary artery (RCA) (c) 


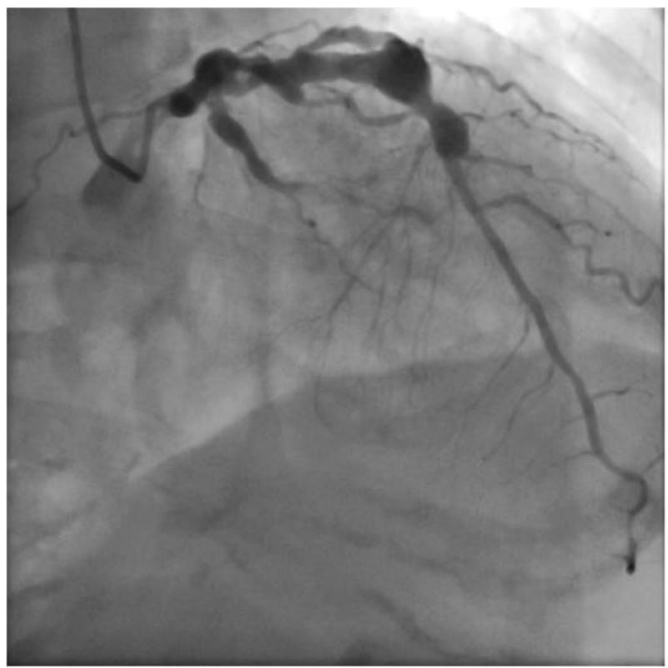

A

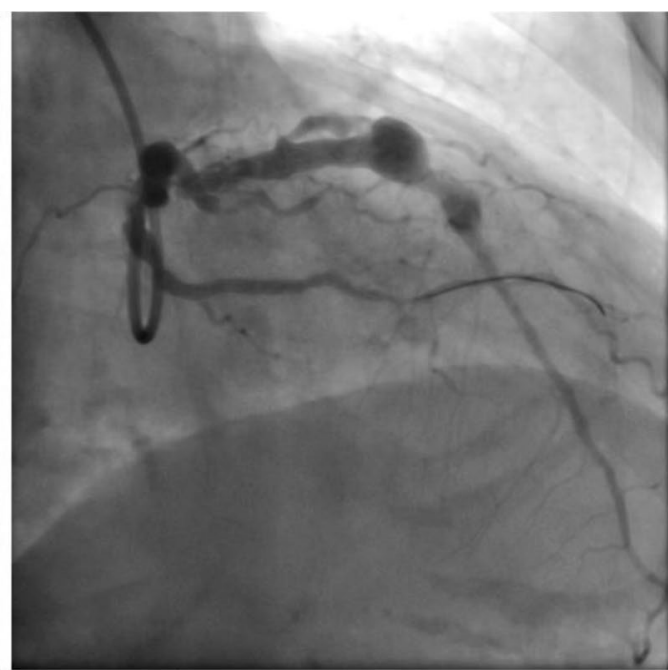

B

Fig. 2 One stent was implanted at the distal end of the LCX (a). Repeated coronary angiography revealed that the occlusion was recanalized and TIMI grade III flow was restored (b)

was restored (Fig. 2b). Finally, the patient was discharged with resolved chest pain. New oral anticoagulant (rivaroxaban) and dual antiplatelet therapy recommended at discharge. Furthermore patient has ectasia and a significant stenosis in proximal RCA.Coronary angiography was recommended after 1 month, but the patient refused..After 1 month, they were treated with rivaroxaban and aspirin. During 6 months of follow-up, the patient is in good health.

\section{Discussion}

In this study, we reported an active SLE patient with a giant LAD aneurysm. CAA is an irreversible coronary vascular dilatation that occasionally grows to become considered giant with a diameter of more than $8 \mathrm{~mm}$. In early studies, the prevalence of giant CAA was only $0.02 \%$ among all CAA cases, and the pathogenesis generally involves other diseases, including SLE [1]. In SLE-related CAA, autoantibody- and immune complex-mediated arterial media destruction and arterial wall thinning are believed to result in the progressive dilatation of the affected arterial segments [2]. However, long-term use of immunosuppressive drugs may also accelerate coronary artery disease [3]. Thus, it is not possible to completely exclude the effects of steroid therapy on CAA pathogenesis. Is there any role for modifications in medical therapy of SLE for treating this disease? At present, there seems to be no definite answer.Perhaps particular disease-modifying anti-rheumatic drugs might have different effects.

As summarized in Table 1, 16 cases of coronary aneurysm in SLE patients have been reported recently. The average age of these patients was 38 years, and most were women (14 cases). The duration of SLE varied from 1-42 years. Most cases (9 cases) had symptoms of ischemic heart disease caused by embolization or stenosis of the coronary artery. Moreover, more than half (9) of cases had atherosclerosis risk factors in addition to SLE (6 cases with hypertension, 2 cases with hyperlipidemia, and 1 case with a smoking history). It should also be noted that the ANA titer was positive in half of the cases, and only two cases were antiphospholipid antibody positive [6, 7]. Similarly, several typical common features were identified in our case. First, 13 years before the patient was diagnosed with hypertension, the diagnosis of SLE was made. Although anti-lupus medication was never discontinued, the ANA test indicated that the SLE was in the active stage when the patient presented to us. Second, although the patient's hypertension had been controlled, the enzyme profile implied irreversible myocardial infarction. Furthermore, two other clinical markers, hyperlipidemia and nephritis, were also detected.

In this case, as in most other cases of SLE patients with coronary artery stenosis, calcium heparins, aspirin, and clopidogrel hydrogen sulfate were used to prevent thromboembolism $[16,18]$. Aneurysm rupture is difficult to predict and can be catastrophic if it occurs. While the outcome of percutaneous coronary intervention in patients with autoimmune disease remains uncertain [19], coronary angiography verified that stent implantation restored the blood supply in our case. However, for most SLE patients with coronary aneurysms, there are currently no official guidelines for the best treatment 
Table.1 Summary of reports of SLE patients with coronary aneurysm expansion

\begin{tabular}{|c|c|c|c|c|c|c|c|c|}
\hline & Age, years & Sex & $\begin{array}{l}\text { Duration of } \\
\text { SLE, years }\end{array}$ & Location (s) & Symptom (s) & Risk factor (s) & ANA & APLAs \\
\hline Present case & 53 & $\mathrm{~F}$ & 20 & LAD, LCX, RCA & $\mathrm{CP}$ & $\mathrm{H}$ & $1: 320$ & none \\
\hline Geiser [4] & 29 & $\mathrm{~F}$ & 6 & LAD, LCX, RCA & Confusion & $\mathrm{H}$ & ND & ND \\
\hline $\mathrm{Ha}[5]$ & 21 & $\mathrm{~F}$ & 1 & $\mathrm{RCA}$ & PT & ND & ND & ND \\
\hline Suzuki [6] & 31 & $\mathrm{~F}$ & 20 & LCX, RCA & None & None & - & + \\
\hline Hirata [7] & 34 & $\mathrm{~F}$ & 12 & LAD, RCA & $\mathrm{CP}$ & None & ND & + \\
\hline Monigari [8] & 30 & $\mathrm{~F}$ & 3 & LAD & None & None & ND & ND \\
\hline Matayoshi [9] & 29 & $F$ & 6 & LAD, LCX, RCA & None & None & $1: 160$ & - \\
\hline \multirow[t]{2}{*}{ Wilson [10] } & 25 & M & 8 & LAD & $\mathrm{CP}$ & $\mathrm{ND}$ & $1: 2560$ & - \\
\hline & 44 & $\mathrm{~F}$ & 11 & LAD & $C P$ & $\mathrm{H}$ & $1: 1280$ & ND \\
\hline Caracciolo [11] & 22 & $\mathrm{~F}$ & 4 & LAD & $C P$ & $\mathrm{SH}$ & $1: 320$ & - \\
\hline Uchida [12] & 55 & M & 42 & LCX, RCA & $\mathrm{CP}$ & $\mathrm{H}, \mathrm{HL}$ & $1: 80$ & ND \\
\hline Yoshikai [13] & 49 & $\mathrm{~F}$ & 10 & RCA & AMI & $\mathrm{HL}$ & $1: 640$ & ND \\
\hline Anna [14] & 65 & $\mathrm{~F}$ & 7 & RCA & $\mathrm{CP}$ & $\mathrm{H}$ & $1: 300$ & ND \\
\hline Famularo [15] & 32 & $\mathrm{~F}$ & ND & LAD, LCX, RCA & None & $\mathrm{H}$ & $N D$ & ND \\
\hline Nobrega [16] & 26 & $\mathrm{~F}$ & 12 & $L A D, R C A$ & None & ND & ND & - \\
\hline Nagao [17] & 62 & $\mathrm{~F}$ & 20 & LAD & $C P$ & ND & ND & ND \\
\hline
\end{tabular}

LAD: left anterior descending artery, LCX: left circumflex branch, RCA: right coronary artery, AMI: acute myocardial infarction, CP: chest pain, DR: dyspneic respiration, H: hypertension, HL: hyperlipidemia, ND: no description provided, SH: smoking history, PT: pericardial tamponade, ANA: antinuclear antibody, APLAs: antiphospholipid antibodies

strategies. Therefore, SLE patients with risk factors such as hypertension, hyperlipidemia, and nephritis, should be offered CAA screening to avoid delays in diagnosis and treatment. At the same time, more clinical trials are required to verify the appropriate therapy for coronary dilatation in the context of SLE, particularly for large aneurysms.

\section{Conclusion}

Our case study, together with 16 recent comparable reports, emphasizes the need for coronary aneurysm screening in SLE patients. It is necessary that thromboembolism, anticoagulation and antiplatelet therapy were administered for CAA.

\section{Abbreviations}

CAA: Coronary artery aneurysm; SLE: Systemic lupus erythematosus; LAD: Left anterior descending artery; LCX: Left circumflex artery; TIMI:Thrombolysis in myocardial infarction; ANA: Antinuclear antibodies.

\section{Acknowledgements}

Thank the Medjaden Bioscience for editing and proofreading this case.

\section{Authors' contributions}

This case was written by ZY. YL is responsible for data collection. ZZ is responsible for data processing. LW is responsible for review and typesetting. All authors read and approved the final manuscript.

\section{Funding}

None.

Availability of data and materials

This case is true and effective.

\section{Declarations}

Ethics approval and consent to participate

This case is based on retrospective study, so there is no need for ethical approval.

\section{Consent for publication}

The patient has provided informed consent for publication of the case.

\section{Competing interests}

The Authors declare that there is no conflict of interest.

\section{Author details}

${ }^{1}$ Department of Cardiology, The First People's Hospital of Tianmen, Tianmen 431700, China. ${ }^{2}$ Department of Cardiology, The First People's Hospital of Jining, Jining 272000, China. ${ }^{3}$ Department of Cardiovascular Center, The First Hospital of Jilin University, No.71 Xinmin Street, Changchun 130021, China.

Received: 6 August 2021 Accepted: 6 November 2021

Published online: 21 November 2021

\section{References}

1. ElGuindy MS, EIGuindy AM. Aneurysmal coronary artery disease: An overview. Glob Cardiol Sci Pract. 2017. https://doi.org/10.21542/gcsp.2017.26.

2. Solow EB, Vongpatanasin W, Skaug B, Karp DR, Ayers C, de Lemos JA. Antinuclear antibodies in the general population: positive association with inflammatory and vascular biomarkers but not traditional cardiovascular risk factors. Clin Exp Rheumatol. 2018;36(6):1031-7.

3. La Paglia GMC, Leone MC, Lepri G, et al. One year in review 2017: systemic lupus erythematosus. Clin Exp Rheumatol. 2017;35(4):551-61.

4. Dhond MR, Matayoshi A, Laslett L. Coronary artery aneurysms associated with systemic lupus. Clin Cardiol. 1999;22(5):373. https://doi.org/10.1002/ clc.4960220515. 
5. Ha VuN, Duttmann R, De Bels D, Devriendt J, Reper P. Fatal multiple coronary involvements in a young woman with systemic lupus erythematosus. Acta Clin Belg. 2014;69:460-2.

6. Suzuki H, Fujigaki Y, Mori M, et al. Giant coronary aneurysm in a patient with systemic lupus erythematosus. Intern Med. 2009;48:1407-12.

7. Hirata K, Yagi N, Wake M, et al. Coronary steal due to ruptured right coronary aneurysm causing myocardial infarction in a patient with systemic lupus erythematosus. Cardiovasc Diagn Ther. 2014;4(4):333-6. https://doi. org/10.3978/j.issn.2223-3652.2014.07.02

8. Monigari N, Poondru RR, Shetty RK, Vivek G. Giant coronary aneurysm presenting as acute coronary syndrome in a patient with systemic lupus erythematosus. BMJ Case Rep. 2014. https://doi.org/10.1136/ bcr-2014-204009.

9. Matayoshi AH, Dhond MR, Laslett LJ. Multiple coronary aneurysms in a case of systemic lupus erythematosus. Chest. 1999;116:1116-8.

10. Wilson VE, Eck SL, Bates ER. Evaluation and treatment of acute myocardial infarction complicating systemic lupus erythematosus. Chest. 1992;101:420-4.

11. Caracciolo EA, Marcu CB, Ghantous A, Donohue TJ, Hutchinson G. Coronary vasculitis with acute myocardial infarction in a young woman with systemic lupus erythematosus. J Clin Rheumatol. 2004;10:66-8.

12. Uchida $\mathrm{T}$, Inoue $\mathrm{T}$, Kamishirado $\mathrm{H}$, et al. Unusual coronary artery aneurysm and acute myocardial infarction in a middle-aged man with systemic lupus erythematosus. Am J Med Sci. 2001;322:163-5.

13. Yoshikai M, Hamada M, Takarabe K. Coronary artery aneurysm with systemic lupus erythematosus. Jpn J Thorac Cardiovasc Surg 2004;52:379-82.
14. Posadzy-Malaczynska A, Woznicka-Leskiewicz L, Juszkat R, Frankiewicz $\mathrm{M}$, Kociemba A. Right coronary artery aneurysm with fistula into the coronary sinus in patient with systemic lupus erythematosus. Kardiol Pol. 2013;71:1329.

15. Famularo G, Vallone A, Compagnucci M, Capo G, Minisola G, Gasbarrone L. Tiny bubbles: coronary aneurysms and lupus. Am J Med. 2014;127:933-5.

16. Nobrega TP, Klodas E, Breen JF, Liggett SP, Higano ST, Reeder GS. Giant coronary artery aneurysms and myocardial infarction in a patient with systemic lupus erythematosus. Cathet Cardiovasc Diagn. 1996;39:75-9.

17. Nagao T, Ito K, Tsuboi H, Ide Y. Rare complications of systemic lupus erythematosus. Intern Med. 2012;51:3101-2.

18. Yousef Yengej FA, Limper M, Leavis HL. Statins for prevention of cardiovascular disease in systemic lupus erythematosus. Neth J Med. 2017;75(3):99-105.

19. Lai CH, Lai WW, Chiou MJ, et al. Outcomes of percutaneous coronary intervention in patients with rheumatoid arthritis and systemic lupus erythematosus: an 11-year nationwide cohort study. Ann Rheum Dis. 2016;75:1350-6.

\section{Publisher's Note}

Springer Nature remains neutral with regard to jurisdictional claims in published maps and institutional affiliations.
Ready to submit your research? Choose BMC and benefit from:

- fast, convenient online submission

- thorough peer review by experienced researchers in your field

- rapid publication on acceptance

- support for research data, including large and complex data types

- gold Open Access which fosters wider collaboration and increased citations

- maximum visibility for your research: over $100 \mathrm{M}$ website views per year

At BMC, research is always in progress.

Learn more biomedcentral.com/submissions 